\title{
Slavery and Beauty in Petronius
}

\author{
COSTAS PANAYOTAKIS \\ University of Glasgow
}

\section{Preliminary remarks}

The purpose of this article is to consider the ambivalent relationship of master and slave in the Satyrica, and to focus on the portrayal of physical beauty, sexual attraction, and power with regard to free men and slaves, especially male slaves, or characters who pretend to be slaves.

In the first part of the article, I support the contested view that the protagonists Encolpius and Giton are neither slaves nor freedmen but free men, and I show that their free status, in harmony with the subversive character of the novel, brings them mostly disempowerment, danger, and trouble, whereas their disguise as (Eumolpus') 'slaves' provides them (albeit temporarily) with safety, opportunities for erotic pleasure, and material goods. This subversion of the potential advantages of free social status has interesting implications both for the perception and legitimization of slavery as social institution and for the unpredictability and uncertainty of life in Encolpius' bleak world. In the second part of the article, I explore how, in contrast to the Greek novelistic ideology which dictates that beauty and slavery are conflicting concepts, the sexual objectification and exploitation of handsome male slaves in Petronius, especially in the Cena Trimalchionis, echoes well-attested Roman male-to-male sexual practices but also complicates our understanding of them. I argue that the vocabulary of male slavery and physical beauty in Encolpius' sophisticated narrative is socially and intertextually nuanced, and reveals Petronius' linguistic originality, the narrator's haughty personality, Trimalchio's influence on him, and the destabilization of societal norms and authority figures in the text.

The paper advances Petronian scholarship, research on beauty in the ancient world, and scholarship on Imperial social history, because it demonstrates through close reading of select episodes of the Satyrica and through general discussion of the Latin vocabulary of male slavery (puer, servus) and physical beauty (pulcher, 
formosus, (in)speciosus, decorus, bellus) that slavery and physical beauty in the Satyrica - a text often (and perhaps wrongly) regarded as a mirror-image of Roman society - are fluid concepts that cannot always be defined in complete opposition to freedom and ugliness respectively.

\section{The social status of the protagonists and its implications}

To what social level do the protagonists belong? Presumably they are free (liberi), otherwise Corax, the hired mercennarius, who farted in an Aristophanic fashion while complaining that Encolpius, Giton, and Eumolpus have given him too much to carry during the episode at Croton, would not have said to them: 'I am as free an individual as you are' (nec minus liber sum quam vos, 117,12). ${ }^{1}$ But had Encolpius, Giton, and Ascyltus always been free? In other words, although they seem to be liberi, are they also ingenui ('free-born')? Because of the fragmentary state of the text we can only speculate on this issue. Courtney believes that they belonged 'to the large class of educated freedmen, of undetermined ethnic background'. ${ }^{2}$ His arguments for this are (i) that Encolp(i)us is a common slave-name, which suggests (to Courtney) that our Encolpius might well have been a puer delicatus who acquired his freedom through sexual favours; (ii) that Giton is said by an angry Encolpius to have stayed in an ergastulum, a slave-prison, performing a woman's task (presumably a sexual one) $(81,5)$; (iii) that Ascyltus is described, again by an angry Encolpius, as stupro liber, stupro ingenuus $(81,4)$ 'he acquired freedom and free birth through depravity'3 or, literally, 'free because of stuprum, free-born also because of stuprum' (stuprum is impossible to translate into English with one word and refers to the violation of the sexual integrity, the pudicitia, which only Roman citizens possess; ${ }^{4}$ Courtney therefore believes that Ascyltus' master had been forcing Ascyltus to penetrate him in exchange for a false claim of freedom; in other words, the master would have falsely testified that Ascyltus was a free-born Roman citizen), ${ }^{5}$ (iv) that the claims Eumolpus makes to Lichas and Tryphaena about Encolpius and Giton being ingenui and liberi homines, 'freeborn men', on board Lichas' ship $(107,3 ; 107,5 ; 107,20)$ are lies to confuse Lichas

\footnotetext{
${ }^{1}$ Unless otherwise indicated, the translation of all Petronian passages in this article is by Walsh 1996; I have used Müller 2009 for the Latin text.

${ }^{2}$ Courtney 2001, 41. The discussion of the social background of the main characters is in Courtney 2001, 40-42.

${ }^{3}$ This is the translation in Courtney 2001, 41. Walsh 1995, 69 has 'a youth not merely free but freeborn devoted to debauchery', but this cannot be correct.

${ }^{4}$ On stuprum, see the excellent discussion of Williams 2010, 103-136.

${ }^{5}$ Schmeling 2011, 345 argues for the contrary view more persuasively.
} 
and Tryphaena; and (v) that, when Tryphaena's ancilla tells Encolpius 'if there is a drop of self-respecting blood in you' (Walsh's translation) or, literally, 'if you have a free-born man's blood' (si quid ingenui sanguinis habes, 113,11), she is merely rebuking him, not stating facts. Courtney could have cited even more passages to support his thesis. For instance, Giton is several times shown to act as a slave would have acted. ${ }^{6}$ His appearance is that of a beautiful pet-boy and in fact both the priestess Quartilla and Trimalchio's freedman-guest Hermeros view him as such. It is important, however, to remember that Giton's character-portrayal is filtered through the eyes of the melodramatic and well-read Encolpius, who has cast his unfaithful and theatrical companion perfectly in the role of the temperamental puer who acts out life through high literature and plays by the rules and conventions of the erastēs/erōmenos type of homoerotic relationship. ${ }^{7}$

Several points in the text militate against Courtney's interpretation. ${ }^{8}$ When Encolpius plots his revenge against Ascyltus, because he (= Ascyltus) stole Giton from him, Encolpius exclaims: 'either I am no man, no free citizen, or I will avenge my wrongs with their guilt-stained blood' (nam aut vir ego liberque non sum, aut noxio sanguine parentabo iniuriae meae, 81,6); here Encolpius the narrator visualizes his former self, Encolpius the protagonist, soliloquizing in the manner of a forlorn and abandoned character from tragedy or epic; ${ }^{9}$ but, although the irony behind the reference to Encolpius' masculinity is clear and amusing, it is difficult to see why he would have lied in this context about his social status, given that there is no immediate audience listening to his words. Moreover, when Encolpius and Giton find themselves on board Lichas' ship and realize that they are in grave danger, they start devising implausible scenarios (one of them, in fact, involves disguising themselves as slaves) in order to escape unnoticed (101,7-

6 'When I asked my boyfriend whether he had cooked anything for our lunch' (cum quaererem numquid nobis in prandium frater parasset, 9,2); 'no sooner had we filled our bellies with the dinner which Giton had kindly prepared for us' (sed ut primum beneficio Gitonis praeparata nos implevimus cena, 16,1); 'Giton was playing the role of servant with great élan' (Gitona libentissime servile officium tuentem, 26,10); 'Giton, who was standing at my feet' (Giton, qui ad pedes stabat, 58,1); ' 'But now', he said, 'we must divide the boy as well', (age nunc et puerum dividamus, 79,12); 'I caught sight of Giton ... you could see that he was not enjoying his menial role' (video Gitona ... scires non libenter servire, 91,1).

${ }^{7}$ Quartilla and Giton: 24,5; Hermeros and Giton: 58,2-7; the latest contribution to Giton's complex character-portrayal is Makowski 2012, but there is still a lot to be gained through reading George 1966.

${ }^{8}$ Habermehl 2006, XVIII-XIX; Vannini 2010, 4 and 182-183. But Richlin 2009, $86-88$ concludes: 'Both the sexual and social status of all three characters seems mischievously indeterminate in the novel; they are living outside the law' (quotation from page 88).

${ }^{9}$ Laird 1999, 221-224; Habermehl 2006, 45; neither Courtney 2001 nor Schmeling 2011 comments on the use of liber in this striking phrase. 
103,4). ${ }^{10}$ The objection put to one of these schemes is that Encolpius and Giton are 'young fellows, not used to discomfort' (iuvenes adhuc laboris expertes, $102,12)$, a description that hardly applies to slaves or former slaves. Finally, the psychological and verbal tension generated between the linguistically challenged and insecure guests of Trimalchio, on the one hand, and the parasites Agamemnon, Encolpius, Giton, and Ascyltus, on the other,${ }^{11}$ cannot in my mind be accounted for satisfactorily if we argue that all of these people are liberti. Despite the ambiguity of the extant text, then, I am inclined to conclude that certainly Eumolpus, in all likelihood Encolpius and Giton, and probably also Ascyltus are freeborn men who are circulating in the gutter of Roman society and are well read, or scheming enough to pass off as well read, in order to exploit whomever they encounter.

It is noteworthy, however, that, despite his free social status, Encolpius does not manage to gain any significant material goods during his troublesome adventures in the low-life society of the extant Satyrica. An old woman deceives him (7,1-4); there is no point in him relying on the protection of the law $(14,2)$; Quartilla's performance fools him (18,1-3); he feels totally subservient towards, and powerless in front of, the priestess of Priapus $(20,1 ; 24,1)$; although he secured for himself and for his companions a free meal at the house of Trimalchio, he seems to be increasingly unable to cope with the unpredictable behaviour of the social upstart and ends up fleeing the dinner party in panic $(78,8)$. Furthermore, Encolpius' nerve-wracking experience at the freedman's house seems to have somewhat transformed the narrative representation of Encolpius' and Giton's social status in ensuing episodes. It may not be a coincidence that after the episode of Trimalchio's dinner Encolpius and Giton appear to find themselves in emotional discomfort or in perilous circumstances or in disconcerting doubt regarding their future and safety, and on those occasions the initiative for the protection of the protagonists is taken not by Encolpius himself but by a third party, who attempts to solve Encolpius' problems by granting him and Giton the social status

${ }^{10}$ Panayotakis 1995, 144-149; Vannini 2010, 121-149.

${ }^{11}$ See, for example, Hermeros' outburst at Ascyltus' behaviour $(57,1-4)$ and at Giton's disrespectful laughter (58,7), Echion's insecurity-driven cutting remarks against Agamemnon 'Agamemnon, am I right that you are saying "Why is this boring man prattling on?"? I'm doing it because though you're the expert with words, you're saying nothing. You don't belong to our patch, so you sniff at the way we poor buggers talk. We know you're off your head with all that education' (videris mihi, Agamemnon, dicere: 'quid iste argutat molestus?' quia tu, qui potes loquere, non loquis. non es nostrae fasciae, et ideo pauperorum verba derides. scimus te prae litteras fatuum esse, 46,1 ), as well as Niceros' statement 'So let's have a good laugh, though I'm afraid these schoolmen are going to scoff at me. Well, they can please themselves; I'm going to tell my story' (itaque hilaria mera sint, etsi timeo istos scholasticos, ne me [de]rideant. viderint: narrabo tamen, 61,4). 
of slaves. This is what happens, for example, with the poet Eumolpus, who engineers the trick of the shaving of the head and the eyebrows of Encolpius and Giton on board Lichas' ship so that the protagonists, aided by a little bit of ink, may pass as branded runaway slaves and escape the wrath of captain Lichas and his friend Tryphaena (103,1-4; 105,11). It is Eumolpus again who decides that Encolpius and Giton become his slaves $(117,4 ; 117,6)$ in the legacy-hunting mime-plot he is staging en route to Croton to trick the Crotonians and obtain from them material gifts and sexual pleasure. ${ }^{12}$ It is as the slave of Eumolpus and under the pseudonym Polyaenus that Encolpius will attempt (albeit with humiliating results) to have a passionate love-affair with an upper-class woman who calls herself Circe (126,1-7; 127,1-8); she inflicts on him (and threatens him with) a slave's punishment for failing to satisfy her sexually $(132,2-4 ; 139,3)$. In other words, whereas a real-life slave would have hoped to escape the dangers of slavery through the channels of what is conventionally known as formal manumission, Encolpius and Giton, in complete reversal of societal norms and in harmony with the themes of social subversion and reversal of audience expectations that dominate the narrative at Croton, ${ }^{13}$ attempt to escape the dangers of their free life by forfeiting their status as free men. This paradox underlines the chaotic and socially fluid nature of the marginalized low-life world inhabited by the protagonists and by those they encounter (free men and women, freedmen and freedwomen, and male and female slaves); it also reveals Roman upper-class anxieties about slaves' social mobility from slavery to freedom and freedmen's anxieties about their reputation as freedmen, and it demonstrates how unpredictable, insecure, and fragile life is for all of these social categories in Petronius' Rome. Emblematic of these anxieties and of this social fluidity and unpredictability in terms of class and moral standing are the freedman Hermeros' statement that 'I'd rather keep my reputation than have loads of money. Let me say just this: nobody has had to ask me twice to pay up. I was a slave for forty years, but no one knew whether I was slave or free' (ego fidem meam malo quam thesauros. ad summam, quisquam me bis poposcit? annis quadraginta servivi; nemo tamen sciit utrum servus essem an liber, 57,9) and Trimalchio's assertion that 'slaves too are men; they have drunk their mother's milk like the rest of us, even if a malign fate has overtaken them' (et servi homines sunt et aeque unum lactem biberunt, etiam si illos malus fatus oppresserit, 71,1). ${ }^{14}$

12 Panayotakis 1995, 157-160.

${ }^{13}$ Fedeli 1987 and 1988; Courtney 2001, 190-192; Schmeling 2011, 471.

${ }^{14}$ Zeitlin 1971, $663=1999,30$ eloquently describes this anxiety with regard to the ambiguity of the freedmen's class. This anxiety is, I would argue, valid also for the slave class, and Eumolpus (surely a freeborn man) with his cunning schemes that involve the heroes' 'loss of freedom' seems to be suggesting that privileged slavery is more valuable than underprivileged freedom. 
Neither of these claims, of course, is unproblematic, since, in Hermeros' case, it was his good looks and his sexual relationship with his master that contributed to his social rise (et puer capillatus in hanc coloniam veni 'I came to the colony as a long-haired slave', 57,9; dedi tamen operam ut domino satis facerem 'I made a point of pleasing my master', 57,10); as for Trimalchio's humanitarian declaration, it must be borne in mind that his erratic behaviour towards his slaves, especially when he is inebriated, and the literary allusion to Seneca (Ep. 47,1 and $47,10)$ in Trimalchio's words complicate the portrayal of master/slave relationships in the Cena Trimalchionis. ${ }^{15}$ Nonetheless, the fact remains that in Encolpius' world no assumptions should be made about the moral standards of different social classes, and there are no clear boundaries distinguishing slaves, freedmen, and free men in terms of material benefits and of opportunities for social and/or moral rise and fall. Think of the hired services provided by the mercennarius Corax: he is a free man, but he performs (grudgingly) the duty of a caballus to earn a living (117,11-12). Eumolpus' scenarios on board Lichas' ship and at Croton in which downward social mobility is viewed as the most advantageous option for those who, like Encolpius and Giton, were born free but either needed to escape from trouble or were searching for better prospects in life may be yet another comically subversive comment on Seneca's humanitarian views on the treatment of slaves, and they show that, despite slavery's well-established and long-standing role in the running of Roman society, justifying the benefits to be derived from slavery as social condition was still a live and valid issue that was of concern to some Romans.

The vocabulary of slavery in the Cena Trimalchionis and its implications

What terminology do Encolpius (in his capacity as narrator and/or protagonist) and Trimalchio (Petronius' celebrated ex-slave) use to refer to slaves, and what does this terminology reveal about them? ${ }^{16}$ Predictably enough, Encolpius the narrator uses the substantive servus to indicate characters of a servile social status that are unimportant in the narrative and are of little value in moving the plot forward. For example, the narrator refers to two servi who distribute pastry eggs to the guests $(33,4)$; we are not told anything more about them. These servi are normally unnamed (a notable exception is Trimalchio's slave Mithridates, who was crucified because he had cursed, it seems, the genius of his master $(53,3)$; but

\footnotetext{
${ }^{15}$ Sullivan 1968, 132-135; Schmeling 2011, 182 and 290-291.

${ }^{16}$ In my research on the vocabulary of slavery and beauty in the extant Petronius I was greatly aided by the two Indices Petroniani: Korn - Reitzer 1986 and Holland - Dominic 2013.
} 
there is good reason for giving him a name in the context), ${ }^{17}$ and they remain unnamed even when the same servus appears more than once in a scene in Encolpius' narrative. When this happens, Encolpius almost always uses the same noun (servus) to refer to him and avoids the use of the pronouns ille or is to refer to a nameless slave mentioned previously over a long description of an event; he simply continues to employ the term servus, and this practice gives his narrative clarity and consistency (but also predictability and simplicity). The narrator's linguistic feature (that is, repeating the referent, servus, as subject of a series of verbs in an extended passage as opposed to using the pronouns is or ille in place of the referent) is not, of course, peculiar to Petronius as literary author, but it is worth pointing out, as Adams has already done, that, when Petronius has freedmen speak and refer to the same person over an extended passage without any possibility of confusion with another person, they remarkably use the demonstrative ille (instead of the commonly expected is) referring to the same referent (see, for example, 37,8-38,4; 38,11-16; 42,3-6; 43,2-8; 45,5-6; 46,7-8; 57,2-3). The usage, which occurs also in the non-literary letters of Petronius' near-contemporary Claudius Terentianus, is, for Adams, an indication of 'the beginnings of the disappearance from use of the pronoun is, with ille assuming its function in the type of context which we have looked at (where a single person is the subject of discussion)' ${ }^{18}$ For the purposes of our analysis, though, Encolpius' repetition of the referent servus in descriptions of events involving the same slave may form a conscious attempt on Encolpius the narrator's part to differentiate himself linguistically and stylistically from the non-standard speech of Trimalchio's freedmen guests. More importantly, the repetition is deliberately meant to remind the reader that Trimalchio's household abounds in slaves and that Trimalchio is their powerful dominus. An example of this may be seen at 30,7, when a servus despoliatus appears in front of Encolpius and his friends begging them to help him; this character is mentioned again three times $(30,9 ; 30,10 ; 31,1)$ on the same Teubner page in which the incident takes place, and he is always defined as servus. We do not see him again.

17 The name Mithridates is well attested as a slave's name in the first century A.D. and thus reflects real-life practice (see Solin 1996, 254), but Petronius may here also be looking back to Republican Roman history, since he has given the name of Rome's fiercest enemy in the first century B.C. to a slave who is duly executed for being disrespectful towards the authority of the almighty Trimalchio (he would never have allowed someone called Mithridates to get off scot-free).

18 Adams 2003, 13-17. The quotation comes from page 17. See also Pinkster 2015, 1147. 
The same consistency is shown when we look at scenes in Trimalchio's dinner party that involve the use of the noun puer, an ambiguous word which may denote 'a young male child' (who is a free person) or 'a young male slave': 19 if the narrator mentions the same boy or slave-boy several times in a brief episode, he repeatedly refers to him as puer $(52,4,52,5,52,6)$ without using the pronouns ille or is to refer to him again. I have found only one instance in the episode at Trimalchio's dinner in which the substantives servus and puer are mentioned with regard to the same person: after a slave-boy had fallen on Trimalchio and bruised his arm, Trimalchio's wife and the rest of the household are shocked with horror and would happily see the slave dead. Trimalchio, however, forgives the slave, and the narrator concludes the story by mentioning that 'Trimalchio, instead of having the young acrobat punished, issued a decree declaring him free, to ensure that no one could claim that a man of such eminence had been wounded by a slave' (in vicem enim poenae venit decretum Trimalchionis quo puerum iussit liberum esse, ne quis posset dicere tantum virum esse a servo vulneratum 54,5 ). Here the linguistic alternation between puer and servus is an intentional stylistic choice, because it enhances the social contrast between tantus vir and servus and adds to the alliterative effect of the clause (virum esse a servo vulneratum).

In general terms, Encolpius the narrator prefers to use the noun puer and to combine it with a descriptive adjective or with an adjective of ethnic origin or with a secondary clause, when he wants to refer not to a 'male child' but to a 'young male slave': for instance, early on in the narrative of Trimalchio's dinner party 'some Alexandrian slave-boys (pueris Alexandrinis) poured iced water on our hands, while others [presumably 'slave-boys' is to be understood here too] behind them bent over our feet, and with great dexterity cut our toenails' $(31,3)$; later on, we are told that 'one of the Alexandrian slaves (puer Alexandrinus), who was providing the hot water, began to imitate nightingales' $(68,3) \cdot{ }^{20}$ The adjective

${ }^{19}$ OLD s.vv. 1 and 5; TLL X,2,2 2517,64-2518,62 and 2519,70-2520,43. The noun is constantly employed with reference to Giton $(9,2 ; 9,10 ; 11,1 ; 24,5 ; 25,3 ; 26,3 ; 58,1 ; 79,4$; $79,12 ; 80,3 ; 80,5 ; 91,5 ; 92,5 ; 93,4 ; 97,2 ; 98,3 ; 100,1 ; 105,8 ; 110,3 ; 113,7 ; 133,2)$, and this contributes to the perceived ambiguity of his social status. It is not always clear if there is a meaningful difference between a servus and a puer in Trimalchio's dinner party, especially when both nouns refer to a slave.

${ }^{20}$ Other examples of puer + qualifying adjective or secondary clause indicating a 'slave' (not 'male child') include circumferebat Aegyptius puer clibano argenteo panem ('an Egyptian slave was carrying bread round in a silver dish', 35,6); exclamavit unus ex pueris, qui supra hoc officium erat positus ('one of the slaves allotted to this duty cried out', 30,5); paratissimus puer non minus me acido cantico excepit ('A slave was immediately at hand, and took my order while singing in a shrill voice', 31,5); sequebatur puer cum tabula terebinthina ('a slave followed behind him bearing a board of terebinth wood', 33,2); cum forte paropsis excidisset et puer iacentem sustulisset, animadvertit Trimalchio colaphisque 
'Alexandrian' would have connotations of Eastern luxury, beauty, and decadence (as well as attraction) to a Roman, ${ }^{21}$ but how would Encolpius know that these slaves were genuinely 'Alexandrian'? Perhaps there was something in their appearance (their skin-colour or their clothes?) that revealed their origin, or perhaps the slaves were dressed to appear as 'Egyptian' so as to enhance the exoticism of the show Trimalchio offered his guests with his dinner party. In either case, it cannot be denied that pueri play a large part in Trimalchio's life and in the success of his staged dinner-parties, and he would also like them to be remembered on his funeral monument and accompany him even after his life had ended: Trimalchio asks Habinnas to include in the monument et cicaronem meum (presumably that is his pet-boy Croesus, to whom I will return in the following section), et amphoras copiosas gypsatas, ne effluant vinum. et unam licet fractam sculpas, et super eam puerum plorantem (' $<$ put in $>$ my boy-favourite, and some big winejars sealed with gypsum to ensure that the wine doesn't leak out. You can show one of the jars as broken, with a slave weeping over it', 71,11).

Trimalchio's use of the word servus is (unsurprisingly) coloured by his past experience as a slave: when he first refers to the slaves who surround him and his guests in the dining-room, he rather ungraciously calls them 'utterly stinking slaves' (putidissimi servi) $(34,5)$. He gives the impression that he wants to erase his servile past, to dissociate himself from his low origins and former humble social condition, and to impress his guests as a hard master. In actual fact, however, he fails to achieve any of this, and this is partly due to his ever-changing moods. Schmeling acutely observes that Trimalchio 'is both kind and brutal towards his slaves, but above all he seems inconsistent: at 28.7 he threatens 100 lashes to any slave leaving the house without permission; at 34.2 he orders a slave to be hit; at 52.4 he orders a slave to beat himself; at 41.7 he frees a slave. It is likely, however, that T.'s harshness towards his slaves is part of a show or mime; no slaves are actually ever harmed; T. had never forgotten his slave past, and his inconsistent treatment of slaves is better seen as a dramatic ploy to create entertainment than as a sign that T.'s character is overly erratic and irresolute. ${ }^{22}$

obiurgari puerum ('in the mêlée, however, a dish happened to fall. As it lay there, a slave picked it up. Trimalchio noticed this, ordered the boy to have his ears boxed', 34,2); pueri ad sportellas accesserunt, quae pendebant e dentibus, thebaicasque et caryotas ad numerum divisere cenantibus ('slaves at once approached the baskets dangling from the boar's teeth, and in time to music shared out the fresh and dried dates among the diners', 40,8).

${ }^{21}$ Panayotakis 2010, 109; Schmeling 2011, 110.

${ }^{22}$ Schmeling 2011, 122 and cf. Ramsby 2013, 71-72. The picture, however, of Trimalchio's apparent inconsistency in treating his slaves is further complicated by the implications of 
In Trimalchio's hierarchical world there are several levels and layers of master/slave relationships, but at the top of the social pyramid it is Trimalchio who appears as the ultimate patron and dominus. Employees beneath him, such as Trimalchio's dispensator 'steward' $(30,9)$, have their own clientes 'dependents' and their own slaves, whom they can treat cruelly: when a slave loses a garment that had been given to the dispensator by one of his dependents as a birthday present, the steward calls him nequissimus servus 'good-for-nothing slave' $(30,11)$. Interestingly, when Encolpius is angry with Trimalchio's staff, he uses the word servus instead of puer or instead of whatever other Latin word he would normally have been expected to use to designate the slave's profession in the household: for instance, in indirect speech Encolpius the narrator calls Trimalchio's cook cocus $(49,5 ; 49,6)$, but, when Encolpius reports the words he himself (as protagonist) had said when he was annoyed with the cook because he (the cook) had forgotten to gut a pig, Encolpius calls him servus and nequissimus (not cocus and nequissimus) ('plane' inquam 'hic debet servus esse nequissimus' 'he must obviously be the most slovenly of slaves', 49,7). This subtle variation in emotionally charged discourse reveals Encolpius' calculating and chameleon-like character, since he imitates Trimalchio's behavioral patterns of ostentatious arrogance, and at the same time he flatters his host so as to secure his favour in future.

Two more terms connected with slavery appear in the extant Satyrica, but neither occurs in high frequency, and so it is impossible to offer any meaningful general remarks about their function in the narrative. The diminutive servulus, alluding to a (?slave-)boy's youth and to his affection and loyalty towards his keeper (not necessarily his owner), is used by Trimalchio's freedman-guest Echion, the centonarius (et iam tibi discipulus crescit cicaro meus. iam quattuor partis dicit; si vixerit, habebis ad latum servulum 'my little feller is growing fast, ready to sit at your feet; he can divide by four already. If God spares him, you'll have a young devotee beside you soon', 46,3), ${ }^{23}$ but is also employed by Encolpius the narrator at the episode in Croton to indicate young slaves of no special value (unus ex noviciis servulis subito accurrit 'one of the apprentice-slaves suddenly bustled up', 139,5). The substantive mancipium, perhaps the least personalized and most legally-flavoured term for a slave in the Latin language, ${ }^{24}$ is used by Trimalchio literally to indicate slaves as property (oneravi rursus vinum, lardum, fabam, seplasium, mancipia 'I loaded them up again with wine, bacon, beans, perfumes, slaves', 76,6) and by Trimalchio's guest, the stonemason Habinnas, figuratively as part of

the informal way in which he manumits some of his slaves. On this crucial detail, see Roth 2016 and Bodel in this volume.

${ }^{23}$ Schmeling 2011, 193 has interesting comments on this young boy.

${ }^{24} T L L$ VIII 255,33-256,38 and $O L D$ s.v. 3 a. 
a phrase referring to a skilful slave of his (omnis musae mancipium 'he's a slave of all talents', 68,7).

In sum, then, slavery in the Satyrica is presented as part of the contemporary Roman social reality but not as the lowest social position imaginable; rather, it is portrayed as a fluid social category in the hierarchy of Encolpius' world, a category that offers its members opportunities to overcome dangers, to enjoy safety and material goods in life, and to become as successful as Trimalchio. Not all slaves will of course succeed in life if and when they are formally manumitted, but it cannot be denied that the protagonists of Petronius' novel and many others like them do not have the privileges that Trimalchio or, in fact, many of Trimalchio's servants enjoy; this realization renders problematic the division between freedom and slavery and the benefits to be acquired from each status.

One of the ways for a slave, especially a male slave, to promote himself within the confines of his slavery was, of course, to grant sexual favours to the master and/or the mistress and to take advantage of his good looks. The episode at Trimalchio's house is full of beautiful slaves; the protagonists themselves are handsome men and the objects of sexual attraction for both free men and women as well as for slaves (Encolpius, for instance, at Croton is desired both by the free woman who calls herself Circe and by her maid Chrysis). And so I now turn to the concept of beauty in Petronius' novel to explore whether its portrayal shows signs of unconventional treatment.

\section{The vocabulary of beauty in Petronius and its implications}

The first observation to make is that the sexual exploitation of male slaves in the Satyrica and especially in the Cena Trimalchionis is unsurprising and unoriginal, and this surely reflects the sexual practices of some Romans in Imperial Rome as well as Petronius' intertextual debt to a host of literary genres, which portrayed (seriously or mockingly) the master/mistress-slave sexual relationship. ${ }^{25}$ For example, we are told by the freedman-guest Echion that the accounts-keeper of Glyco 'was forced to push it in' (coactus est facere) with his mistress $(45,8)$. Trimalchio happily confesses that 'I myself used to have it off with my mistress, even incurring the suspicion of my master' (ego sic solebam ipsumam meam debattuere, ut etiam dominus suspicaretur, 69,3), and feels that it was his duty to

\footnotetext{
${ }^{25}$ See Ar. Thesm. 491-492; Xen. Eph. 2,5,1-6; Juv. 6,278-279; Mart. 12,58; Quint. 5,11,34; Tac. Ann. 12,53; Sullivan 1968, 121, n. 1; Rudd 1986, 193-205; Williams 2010, (slaves as men's sexual partners) 16-19, 20-21, 31-40, 51-54, 59-63, 78-79, 83-88, 96-97, 101-109, 284-285, (slaves as women's sexual partners) 55-56; Schmeling 2011, 318-319.
} 
please master and mistress, although he does not add that this would have ensured that the process of obtaining his freedom would have been unproblematic as a result of this sexual relationship (tamen ad delicias [femina] ipsimi [domini] annos quattuordecim fui. nec turpe est quod dominus iubet. ego tamen et ipsimae [dominae] satis faciebam 'still, at the age of fourteen I was my master's favourite - there's no shame in doing your master's bidding. Mind you, I used to keep the mistress happy as well', 75,11). Like many other aspects of his past, Trimalchio has not really let go off this aspect either, and perpetuates the practice of having adorable slaves around him, although this time round he is the master who derives pleasure from the slaves. ${ }^{26}$

For instance, Trimalchio is surrounded by pueri capillati in the playground $(27,1-2) ;{ }^{27}$ this is perhaps the first time that the adjective capillatus occurs in extant Latin literature in the sense that the boy sporting the long hair is to be primarily viewed as an object of desire. ${ }^{28}$ Cicero (Agr. 2,13 and 2,59) seems to have been the first extant Latin author to coin the adjective, but he did so as a sign of hirsuteness forming part of political invective. ${ }^{29}$ Catullus employs the adjective pejoratively with reference to the foreign poet and Catullus' rival-lover Egnatius, who is thus mockingly viewed as puer pathicus and comes very close in terms of Roman sexual norms to the slave-boys erotically decorating Trimalchio's world. ${ }^{30}$ In Petronius (27,1-2), capillatus is without a doubt highly eroticized and given positive (rather than grotesque) aesthetic qualities not because of Trimalchio's sexual preferences for slave-boys (after all he renders the scene in the playground comic with his colourful garments and his absurd ball-playing) but through the internally focalized comment of Encolpius, who notes that the boys with the pageboy hairstyle 'were worth a good look' (nec tam pueri nos, quamquam erat operae pretium, 27,2). The aside of the narrator to the reader is meant to indicate that Encolpius' and Trimalchio's conceptualization of male beauty is identical: at this

${ }^{26}$ Richlin 2009, 90.

${ }^{27}$ Richlin 2009, 89-90 offers interesting observations on 'slave sex' and the presence of pueri capillati in the episode at Trimalchio's dinner party.

${ }^{28}$ See $O L D$ s.v. $1 \mathrm{~d}$ and TLL III $313,35-51$.

${ }^{29}$ Harvey 1972, 32: 'the comments on Rullus' hirsuteness (capillatior quam ante barbaque maiore), moreover, bear comparison with Cicero's frequent disapproval of aristocratic barbatuli iuvenes'.

${ }^{30}$ Cat. 37,17 tu praeter omnes une de capillatis 'and you above all, unique among all the long-haired men' (Godwin's translation), and see Booth 1985 for the (correct, in my view) interpretation of the adjective as an indication of unmanliness. Godwin 1999, 156 (and many other commentators on the poem) miss(es) the point by ignoring the sexual insinuation of the line: 'it seems to have been the fashion among young men to wear their hair long (see e.g. Petronius Satyricon 27.1) and Egnatius is perhaps continuing to do so after his youth has long gone and so is "unique" in this way.' 
early stage in the narrative Encolpius is still hopelessly in love with Giton, while Trimalchio grew up in a culture where pueri capillati were meant to please their master and mistress; Trimalchio remembers himself as capillatus (cum adhuc capillatus essem, nam a puero vitam Chiam gessi 'when I was still a long-haired lad (even from my early years I lived as the Chians do)', 63,3), ${ }^{31}$ and Hermeros reveals that he was a servus and a puer capillatus who did everything to satisfy his master (57,9, cited above); therefore, Trimalchio, who is portrayed as capillatus on the mural of the slave-market (venalicium) that Encolpius, Giton, and Ascyltus viewed very shortly after they observed the real pueri capillati on the playground $(29,2)$, recreates the past by having long-haired (slave)boys in the playground in order that he, who is no longer young and long-haired (the first two points Encolpius the narrator makes upon seeing Trimalchio focus on the freedman's age and his baldness: senem calvum, 27,1), may both cling on to his young beautiful image and indicate that he has now moved on in society since his youngslave days; he is now the master and he even has pueri capillati bringing perfume into the dining-room to wash the feet of the diners $(70,8)$. We are also told that, after a puer had been punished for picking up a dish that had accidentally fallen on the floor, 'two long-haired Ethiopians moved in' (intraverunt duo Aethiopes capillati, 34,4). They could be actual Ethiopian slaves, a sign of ostentatious luxury, or Trimalchio's low-life pet-boys made up as Ethiopians to give the impression to the guests that the host's personnel is exotic and the host wealthy. ${ }^{32}$ One can never be sure with Trimalchio, but regardless of whether or not these beautiful boys are dressed up as Ethiopians, we have here an instance of physically attractive slaves displayed as expensive objects and symbols of wealth that enhance the status of the slave-owner.

The same impression (of beauty as status symbol and luxurious possession that can be displayed for the admiration and envy of the beholder) is given when we consider Trimalchio's favourite pet-boy (his deliciae), who, in his horse-play with the host, demonstrates that he is the real authority figure in the relationship with Trimalchio (Trimalchio ... basiavit puerum ac iussit supra dorsum ascendere suum. non moratus ille usus <est> equo manuque plana scapulas eius subinde

\footnotetext{
${ }^{31}$ On 'living as the Chians did', see Schmeling 2011, 260 with further bibliography.

${ }^{32}$ For the former possibility, see Courtney 1999, 84: 'Long-haired Ethiopians is a contradiction in terms; these are the long-haired pages common in Roman households (27.1, 57.9, 70.8; Trimalchio himself 29.3, 63.3) with blackened faces (cf. 102.13), another case of things which are not what they seem. Actual Ethiopian slaves were a popular form of ostentation.' For the contrary view, see Schmeling 2011, 121: 'Ethiopian boys, i.e. boys of colour, are known for their crispi capilli, but there is no reason why they should not have long hair. ... At 102.13 there is a discussion about disguising Encolpius and Giton as Ethiopians, but there is no mention of shortening the hair.'
} 
verberavit 'Trimalchio ... kissed the boy, and told him to mount his back. Croesus promptly played the jockey, and kept striking Trimalchio's shoulders with the flat of his hand', 64,11-12); ${ }^{33}$ Encolpius the narrator is scathing about the boy's level of physical attractiveness: 'a go-cart, in which his boy-favourite was riding, a wizened youth with watery eyes, uglier than Trimalchio his master' (chiramaxio, in quo deliciae eius vehebantur, puer vetulus, lippus, domino Trimalchione deformior, 28,4). Later in the narrative (64,5-6) Encolpius will reveal his name (Croesus) and will describe him as 'a lad endowed with watery eyes and hideously rotting teeth' (puer autem lippus, sordidissimis dentibus). One may well wonder whether Encolpius' description is accurate, and (if so) ask how it is possible for Trimalchio, when surrounded by so many beautiful male slaves, to have selected as his deliciae someone whom the narrator describes as so unattractive. Commentators have attempted to explain Croesus' appearance (including the oxymoronic phrase puer vetulus) and Trimalchio's affection for him as a joke. ${ }^{34}$ However, in the most recent discussion of the passage, Lowe has put forth a convincing argument showing that Croesus, along with the son of Euthymenes of Salamis, the son of Cornelius Tacitus, and other (unnamed) young people of the Imperial period (all discussed by Pliny the Elder and Seneca the Younger), suffered from a 'rare genetic illness [now] known as Hutchinson-Gilford syndrome or juvenile-onset progeria [that] causes rapid premature ageing from infancy'. ${ }^{35}$ This interpretation reinforces the strong impression we get from innumerable other instances in Trimalchio's dinner party that the uncouth millionaire loves to show off and display his wealth in any way and form. 'Wealthy Romans throughout the Imperial period', says Lowe, 'acquired slaves with congenital deformities, and indeed exotic pets, for both entertainment and rarity value. ... For a connoisseur like Trimalchio, to whom rarity and expense were more important than conventional charm, the display value of such a deliciae would be considerable. ${ }^{36}$ I wonder therefore whether Encolpius recognized the monetary value of this individual but, out of envy for Trimalchio's success, focussed on Croesus' unattractive features or whether he simply did not recognize Croesus as an item of luxury and described him merely as he saw him, thus implying that the ugliness of the pet-boy reflected negatively on the master.

${ }^{33}$ Croesus' character, blurring the boundaries of the master/slave and the human/animal categories in terms of authority and power, has been effectively discussed by Slater 2013.

${ }^{34}$ So, for instance, Richlin 2009, 90. Schmeling 2011, 92 explains Croesus' appearance as the result of 'the precocious ageing of pathics (and eunuchs) [which] has already been hinted at 23.3 v. 4 ueteres and 23.5 rugas malarum' (with reference to the physical characteristics of the cinaedi in the Quartilla episode).

${ }^{35}$ Lowe 2012; the citation is from page 883.

${ }^{36}$ Lowe 2012, 885. 
What is the vocabulary of beauty employed in the extant Satyrica by various characters (including Encolpius the protagonist) and conveyed to us through Encolpius the narrator, and how has it been distributed to the various social classes and genders featuring in the novel? Of the Latin vocabulary pertaining to the physically beautiful as applied to humans - namely the adjectives pulcher, formosus, speciosus, bellus, and decorus (and the associated abstract nouns pulchritudo, formositas, species, and decor) - Encolpius uses formosus and its superlative degree only of young Giton $(97,2)$, of Eumolpus' object of sexual attraction, the young boy from Pergamum $(85,1 ; 85,2)$, and of Tryphaena $(101,5)$, all of them freeborn characters. Giton, especially, is a boy with mirabili forma, which, like the beauty of Helen of Troy that captivated the soldiers, disarmed the sailors on board Lichas' ship $(105,7) \cdot{ }^{37}$ Konstan, building on the detailed study of Monteil regarding the Latin terminology of beauty, writes: 'Pierre Monteil argues that formosus applies primarily to visible shape (forma), above all to the human form. Monteil points out that in archaic texts the term is commonly applied to men (only once to a woman in comedy: Terence, Eunuch, 730), and signifies a healthy or strong body. From the time of Cicero onward, it acquires the more general sense of good proportion, even in connection with abstract entities, and comes to be applied especially to women (occasionally to men or boys) in amorous contexts, where formosa alone may indicate "la belle," that is, "a beauty". ${ }^{38}$ Encolpius' distribution of formosus squares with the conventional use of the adjective that emphasizes the forma of a person and stresses the effeminate character of men (like Giton and the Pergamene boy) who are qualified as formosi.

Like formosus, pulcher is yet another adjective that Encolpius does not attribute to any slave in the extant narrative. Monteil believes that 'without a doubt, pulchritudo expresses the idea of beauty; but it is not so much physical and anatomical (forma) as supernatural and symbolic of prosperity'; Konstan qualifies Monteil's views and concludes that, 'when [pulcher] modifies human subjects, it regularly signifies 'beautiful', and the emotional response that it evokes is erotic desire or amor'. ${ }^{39}$ Encolpius employs pulcher in the basic degree with reference

${ }^{37}$ I owe this observation — splendidly revealing Giton's manipulative beauty — to Vannini $2010,168$.

${ }^{38}$ Konstan 2015a, 148 and Konstan 2015b, 55-56, referring to Monteil 1964, 58-60. See also $T L L$ VI,1 1111, $25-1112,39$ and $O L D$ s.v. a. The substantive formositas does not appear in the extant Satyrica.

39 The first citation comes from Monteil 1964, 76 and was translated into English by Konstan 2015a, 153; the second citation comes from Konstan 2015a, 153 and 2015b, 57. Konstan discusses pulcher (the adjective and the related adverb) fully in 2015a, 151-161 and 2015b, 56-66. See also TLL X,2,2 1-72. The abstract pulchritudo appears twice in the extant $S a-$ tyrica: at 2,6 pulchritudo naturalis is a characteristic of oratio grandis et pudica; in 132,1 
to Venus in a sombre poem-prayer to Priapus (133,3 line 1); in the comparative degree when he addresses himself and Giton in an elevated poem (109,10 line 2) on the loss of hair, and compares them to the gods Apollo and Diana; ${ }^{40}$ the adjective pulcher is employed by Eumolpus in the superlative degree with regard to the Matron of Ephesus; when the soldier first sets eyes on her, she is defined as pulcherrima (visaque pulcherrima muliere 'his eyes fell on this supremely beautiful woman', 111,7); here, however, the adjective is surely meant to echo Dido (cf. Verg. Aen. 1,146 forma pulcherrima Dido) and to pave the way in Eumolpus' narrative for further intertextual engagement between the Carthaginian queen and the Ephesian Matron (111,11-12). ${ }^{41}$ Pulcher applied to a person who evokes amor to her beloved occurs with reference to the sweetheart of the freedman Niceros, Melissa from Tarentum, whose social status is unclear, and whom Niceros amusingly calls 'quite a fetching bit of goods' or 'beauty-butt' (pulcherrimum bacciballum, 61,6). ${ }^{42}$ This is an original phrase not only on account of the imaginative low-register hapax legomenon bacciballum but also because of its combination with the refined term pulcher, an adjective one would not normally associate with Trimalchio's freedmen guests. Niceros uses it deliberately in order to sound erudite and cultured and to impress Trimalchio's new guests, whose criticisms he fears $(61,4)$. The favourite qualifying adjective of the freedmen for the concept of beauty is bellus, which outside the Cena Trimalchionis is employed only by the low-life priestess Quartilla in direct discourse and by Encolpius in indirect speech in the Quartilla episode. ${ }^{43}$ The association of bellus in the Satyrica with non-

the noun is employed by Encolpius as Polyaenus to refer to the physical beauty of Circe (not to a puer called Endymion, as Courtney 2001, 197 n. 12 correctly points out; TLL $\mathrm{X}, 2,2$ 2573, 19-20 is not correct in this respect); the refined term pulchritudo at 132,1 expresses aptly the ethereal, almost divine, beauty of Circe in the eyes of Encolpius, the mythomaniac narrator.

${ }^{40}$ On the problem of the potential addressee(s) of the poem, see Setaioli 2011, 184-185.

${ }^{41}$ Vannini 2010, 252. Vannini 2010, 246 sees in pulcherrima muliere an instance of the Greek novelistic motif of love-at-first-sight, but the Virgilian evocation seems to me to be a stronger intertext here.

${ }^{42}$ For the non-standard hapax legomenon bacciballum and its effective contrast with the respectable adjective pulcher, see Cavalca 2001, 40-41 and TLL II 1667, 37-39. 'Beautybutt' is the translation of Schmeling 2011, 254.

${ }^{43}$ Bellus in the Quartilla episode: 24,7 (belle ... militabit) (Quartilla); 25,1 (bellissima occasio) (Quartilla); 25,2 (puella satis bella) (Encolpius narrator). Bellus in the speeches of the freedmen: 42,3 (homo bellus) (Seleucus); 46,2 (belle erit) (Echion); 51,4 (phialam otio belle correxit) (Trimalchio); 57,3 (bellum pomum, qui rideatur alios) (Hermeros); 58,12 (bella res est volpis uda) (Hermeros); 58,13 (bella res et iste) (Hermeros); 64,2 (canturire belle deverbia) (Trimalchio); 68,2 (si quid belli habes) (Trimalchio); 70,2 (nomen bellissimum) (Trimalchio); 78,5 (dicite aliquid belli) (Trimalchio's last words). The adjective 
standard Latin is unsurprising. "Bellus is relatively rare in classical Latin ... The word perhaps had a colloquial ring and tends to mean "glib" or "slick," often of someone who cultivates appearance rather than quality; ... The term is relatively rare in Cicero and is used most often in his letters, which are more informal than his other works ... Pierre Monteil, in his study of terms for beautiful and ugly in classical Latin, takes bellus to be a diminutive of bonus, and hence to suggest "un bon petit" (233), and to lie at the opposite extreme to pulcher, always connoting an insufficient development of beauty, a lack of maturity (like "cute"). ${ }^{44}$

Beauty-related terminology concerning slaves at Trimalchio's dinner-party is almost always focalized through Encolpius the protagonist, who often embellishes the facts with adjectives or digressive statements, thus betraying his own sexual preferences and beauty aesthetics. An example of this is the puer impersonating Dionysus so as to facilitate Trimalchio's pun on Lïber/līber $(41,6)$. Encolpius the protagonist, as reported by Encolpius the narrator, finds this boy speciosus 'attractive in appearance'. ${ }^{45}$ 'Speciosus, deriving from the noun species or "image," is absent in early Republican literature and occurs only three times in Cicero: once of a gladiatorial troop in a plainly ironic context (Pro Sestio, 134), once of a fine orator with no trace of satire, and once in a letter to Atticus, of a just case or cause (16.7.6). It is also found three times in the continuators of Caesar's war commentaries, and a few times in Columella's treatise on agriculture, where it is used straightforwardly to mean "handsome" or "fine" (in reference to trees and the like). In Quintus Curtius Rufus's history of Alexander the Great (5.1.8, 7.5.20), it begins to approximate the sense of "specious," as again in Horace, where it connotes a false or merely external splendour, as at Epistles, 1.16.44-45 ... Livy employs the term fairly often, and again, there is frequently a suggestion of superficial attractiveness as opposed to genuine value. ${ }^{46}$ Horace (Carm. 3,27,55) and Ovid $(\text { Ars } 3,421)^{47}$ are the authors before Petronius to use speciosus of good-looking women, so it is arguable that the beauty of the boy dressed up as the god of wine not only suits the typical effeminacy of the god Dionysus but also invites us to view him as an object of desire at Trimalchio's dinner party. Of an equally young age, the daughter of the legacy-hunter Philomela, who prostitutes her children to the aged Eumolpus, is characterized by Encolpius the narrator as

occurs also in a short poem in elegiac couplets (41 line 1$)$ in $A L(479 \mathrm{R}=477 \mathrm{SB}=$ fr. 31 B) attributed to Petronius, and its usage there is fully justified by the poem's content.

${ }^{44}$ Konstan 2015a, 149-150; see also TLL II 1856, 48 - 1857, 32.

45 The episode has been recently discussed in an excellent article by Roth from the point of view of the practicalities of manumission and their implication for Encolpius' narrative and the dating of Petronius' novel. See Roth 2016, 618.

${ }^{46}$ Konstan 2015a, 150-151; OLD s.v. 1.

${ }^{47}$ Gibson 2003, 272 ad loc.: 'speciosus emphasizes the aspect of display'. 
speciosissima $(140,4)$, and I imagine that the superlative degree here indicates that she was viewed as an object of sexual desire by both Eumolpus, the false dominus, and Encolpius, his 'slave'. ${ }^{48}$ At 74,8 'among the incoming servants was quite a handsome lad, and Trimalchio went bounding over and gave him a lingering kiss' (cum puer non inspeciosus [another Petronian beauty-related hapax legomenon] ${ }^{49}$ inter novos intrasset ministros, invasit eum Trimalchio et osculari diutius coepit). An epic brawl ensues between Fortunata and her husband, and Schmeling comments: 'Is this a parody of marital strife among the gods, i.e. Juno's anger with Jupiter for loving a mortal woman, or Zeus with Hera (Hom. Il. 15.14-33)? Or perhaps Trimalchio is re-enacting his early life when he was a slave and satisfied the erotic needs of both master and mistress? ${ }^{50}$ Both interpretations are correct, in my view. The first is made possible through Encolpius the narrator, who enjoys elevating to high literature the mundane events he is witnessing, and the second is consistent with Trimalchio's practice elsewhere in the dinner party to hang on to his past. When the quarrel between the spouses calms down, Trimalchio declares: 'I gave this model slave a kiss not because he's handsome, but because he applies himself so well' (puerum basiavi frugalissimum, non propter formam, sed quia frugi est, 75,4-5), and it would be reasonable to assume that through this justification Trimalchio projects onto the unnamed young slave his own memories as a slave, his own former good looks, and his own past relationship with his master.

\section{Concluding remarks}

When I set out to examine the topic of slavery and beauty in Petronius, I expected to find male and female slaves portrayed as objects of desire (regardless of how beautiful they were) according to the sexual practices and the normative rules regarding penetration operating in Roman society from at least Plautus' time. The situation in Petronius is a bit more complex than this, since physical beauty not only is associated with sexual attraction (as one would expect) but also seems to be greatly enhanced by the status of slavery - a connection one would not readily expect to find, for instance, in the Greek novelistic tradition. Therein beauty is associated with erotic attraction and nobility of birth, while slavery renders a

\footnotetext{
${ }^{48}$ Conversely, Encolpius does not find Eumolpus speciosus when the latter first enters into the art-gallery $(83,4)$.

49 OLD s.v. and TLL VII,1 1943, 19-23. On the combination of negative + privative compound adjective non inspeciosus, see Langslow (Wackernagel) 2009, 772-775.

${ }^{50}$ Schmeling 2011, 312.
} 
person less beautiful or even ugly: ${ }^{51}$ you do not find in the Greek canonical novels unpleasant-looking protagonists (however you wish to define aesthetic unpleasantness) or ugly infants (who will turn out to be the protagonists) or characters that are born slaves, remain slaves, and are better-looking than the protagonists. In Achilles Tatius' novel (5,17,3-9), for instance, Clitophon does not recognize Leucippe when she has become a slave, presumably because slavery as a social condition has made her unrecognizable and unattractive in his eyes; her words move him, 'for she seemed to resemble Leucippe somewhat' $(5,17,7)$. Only Melite shrewdly recognizes that the appearance (morfē) of the slave-woman begging her and Clitophon may indicate noble birth (eugeneian) despite her adverse circumstances (kai en kakois) $(5,17,4)$. 'In Chariton's novel Callirhoe, the Greek aristocrat Dionysius exclaims upon hearing that a slave woman excels in beauty (she is in fact Callirhoe, the novel's heroine, who has been abducted from her home country): "It is impossible, Leonas, that a body [sôma] should be kalón if it has not been born [or is not by nature, pephukos] free" $(2,1,5){ }^{,} .{ }^{52}$ Ugly protagonists would not be objects of desire to each other or to third parties. This idealized approach to the concept of beauty is absent in Petronius: for example, Giton, who was beautiful when he had curly hair $(58,2 ; 58,8 ; 97,2)$, remains beautiful and attractive to the sailors, to Tryphaena's maids, and to Tryphaena herself on board Lichas' ship, although he is shaved and allegedly a slave $(105,7) .{ }^{53}$ To be sure, a curly-haired wig and false eyebrows are needed to restore Giton to his former glory (110,1-2), but from the narrator's description, which is filled with terms of beauty and ugliness ${ }^{54}$ it appears that artificial beauty may substitute natural beauty perfectly easily and adequately: we are told that Tryphaena fully recognized Giton after he has had his make-up, and that she even cried and kissed him $(110,3)$. In the same way, Encolpius, whose hair has always been part of his sexual

${ }^{51}$ On beauty in the Greek novels, see Konstan 2015a, 15-16, 69-70.

${ }^{52}$ See Konstan 2015a, 94. The citation comes from footnote 43.

${ }^{53}$ On the shaving of the head as an indication of slavery in the Greek novel, see Ach. Tat. 5,17,5 and 8,5,4; Setaioli $2010=2011$ offers a splendid discussion of the poem dedicated to the loss of hair in the Lichas episode $(109,9-10)$ as symbol of death.

54 ego etiam si repositum in pristinum decorem puerum gaudebam, abscondebam tamen frequentius vultum intellegebamque me non tralaticia deformitate esse insignitum, quem alloquio dignum ne Lichas quidem crederet. sed huic tristitiae eadem illa succurrit ancilla, sevocatumque me non minus decoro exornavit capillamento 'for my part, I was delighted to see the boy restored to his former beauty, but I repeatedly covered up my own face in the realization that I was so conspicuously hideous that Lichas did not consider me worth even addressing. But that same maid lifted my melancholy, for she summoned me away, and adorned me with equally fetching locks' $(110,4-5)$. On the adjective decorus and the substantive decor as Latin terms of beauty, see Konstan 2015a, 151; TLL V,1,1 214, 4-71 and V,1,1 206, 78 - 208, 12; and $O L D$ s.v. decor ${ }^{1} 1$ and s.v. decorus 1a. 
attraction $(18,4 ; 126,2)$, remains beautiful in Croton, although he pretends to be one of Eumolpus' slaves, and clearly sells his good looks to the Crotonians (126,12). Equally significant for the unconventional treatment of authority figures in the Satyrica is the fact that the power in a relationship between a master and his petboy does not always lie with the master, as we have seen in the case of Trimalchio and Croesus. Finally, it is possible to see a difference in the narrative function of beauty when combined with slavery or freedom in the Cena Trimalchionis and in the remainder of the extant Satyrica. There is no one-size-fits-all with regard to slavery in Trimalchio's circle: being beautiful and a slave does help to draw the attention of the dominus or other potential benefactors but may not be enough to facilitate the upward social mobility and manumission of a beautiful slave; conversely, the combination of beauty and free status is portrayed as normally problematic (not beneficial) to him who possesses these qualities, and indicates to the reader that there is trouble ahead in the narrative. ${ }^{55}$

\section{Bibliography}

Adams, J.N. 2003. 'Petronius and New Non-Literary Latin', in: J. Herman - H. Rosén (eds.), Petroniana. Gedenkschrift für Hubert Petersmann, Heidelberg: Universitätsverlag Winter, 11-23.

Booth, A.D. 1985. 'Vne de capillatis ... Egnati', EMC 29, 111-120.

Cavalca, M.G. 2001. I grecismi nel Satyricon di Petronio, Bologna: Pàtron Editore.

Courtney, E. 2001. A Companion to Petronius, Oxford: Oxford University Press.

Fedeli, P. 1987. 'Petronio: Crotone o il mondo alla rovescia', Aufidus 1, 3-34.

- 1988. 'Encolpio-Polieno', MD 20-21, 9-32.

George, P. 1966. 'Style and Character in the Satyricon', Arion 5, 336-358.

Gibson, R.K. 2003. Ovid: Ars Amatoria Book 3, Cambridge: Cambridge University Press.

Godwin, J. 1999. Catullus: The Shorter Poems, Warminster, England: Aris \& Phillips Ltd.

Habermehl, P. 2006. Petronius, Satyrica 79-141. Ein philologisch-literarischer Kommentar, Berlin - New York: De Gruyter.

Harvey, Jr., P.J. 1972. Cicero's Orations De Lege Agraria: Studies and Essays, with a Commentary on the Third Oration, Ann Arbor, Michigan: University of Pennsylvania PhD.

Holland, J.E. - Dominik, W.J. 2013. Petronii Satyricon Concordantia, Hildesheim - Zürich New York: Olms-Weidmann.

${ }^{55}$ I am grateful both to the organisers of RICAN 7, Michael Paschalis and Stelios Panayotakis, for inviting me to contribute (orally and in writing) to the conference on 'Masters and Slaves in the Ancient Novel' and to the conference participants for their useful observations during the discussion of my paper. I owe special thanks to Stelios Panayotakis and Ian Ruffell, with whom I discussed aspects of my argument, as well as to Mario Labate, Giulio Vannini, and Mario De Nonno, who gave me very useful feedback on my ideas. Any errors or inaccuracies are, of course, mine. 
Konstan, D. 2015a. Beauty: The Fortunes of an Ancient Greek Idea, Oxford: Oxford University Press.

- 2015b. 'Beauty and Desire between Greece and Rome', in: D. Cairns - L. Fulkerson (eds.), Emotions between Greece and Rome, London: Institute of Classical Studies, 45-66.

Korn, M. - Reitzer, S. 1986. Concordantia Petroniana. Computerkonkordanz zu den Satyrica des Petron, Hildesheim - Zürich - New York: Olms-Weidmann.

Laird, A. 1999. Powers of Expression, Expressions of Power: Speech Presentation and Latin Literature, Oxford: Oxford University Press.

Langslow, D. (ed.) 2009. Jacob Wackernagel, Lectures on Syntax, Oxford: Oxford University Press.

Lowe, D. 2012. 'Trimalchio's Wizened Boy (Satyrica 28.4)', CQ 62, 883-885.

Makowski, J.F. 2012. 'Petronius' Giton: Gender and Genre in the Satyrica', in: M.P. Futre Pinheiro - M.B. Skinner - F.I. Zeitlin (eds.), Narrating Desire: Eros, Sex, and Gender in the Ancient Novel, Berlin - Boston: De Gruyter, 223-233.

Monteil, P. 1964. Beau et Laid en Latin. Étude de Vocabulaire, Paris: Klincksieck.

Müller, K. (ed.). 2009. Petronii Arbitri Satyricon Reliquiae. Editio Iterata Correctior Editionis Quartae (MCMXCV), Berlin - New York: Walter der Gruyter.

Panayotakis, C. 1995. Theatrum Arbitri: Theatrical Elements in the Satyrica of Petronius, Leiden - New York - Köln: E.J. Brill.

- 2010. Decimus Laberius: The Fragments, Cambridge: Cambridge University Press.

Pinkster, H. 2015. The Oxford Latin Syntax, Volume I: The Simple Clause, Oxford: Oxford University Press.

Ramsby, T. 2013. 'Reading the Freed Slave in the Cena Trimalchionis', in: S. Bell - T. Ramsby (eds.), Free at Last! The Impact of Freed Slaves on the Roman Empire, London - New Delhi - New York - Sydney: Bloomsbury Academic, 66-87.

Richlin, A. 2009. 'Sex in the Satyrica. Outlaws in Literatureland', in: J. Prag - I. Repath (eds.), Petronius: A Handbook, Chichester: Wiley-Blackwell, 82-100.

Roth, U. 2016. 'Liberating the Cena', CQ 66, 614-634.

Rudd, N. 1986. Themes in Roman Satire, London: Duckworth.

Schmeling, G. 2011. A Commentary on the Satyrica of Petronius, Oxford: Oxford University Press.

Setaioli, A. 2010. 'I versi in Petr. Sat. 109.9-10', Prometheus 26, 151-167; reprinted as 'A Dirge on Lost Hair (Petr. 109.9-10)', in: A. Setaioli, Arbitri Nugae: Petronius' Short Poems in the Satyrica, Frankfurt am Main: Peter Lang, 177-191.

Slater, N.W. 2013. 'The Master and Margarita: Figuring Authority in Petronius's Satyrica', in: M. Carmignani - L. Graverini - B. Todd Lee (eds.), Collected Studies on the Roman Novel - Ensayos sobre la novela romana, Ordia Prima Studia 7, Córdoba: Editorial Brujas, 65-76.

Solin, H. 1996. Die Stadtrömischen Sklavennamen. Ein Namenbuch, Stuttgart: Franz Steiner Verlag.

Sullivan, J.P. 1968. The Satyricon of Petronius: A Literary Study, London: Faber and Faber Limited.

Vannini, G. 2010. Petronii Arbitri Satyricon 100-115. Edizione critica e commento, Berlin New York: De Gruyter.

Walsh, P.G. 1996. Petronius: The Satyricon, Oxford: Clarendon Press.

Williams, C.A. $2010^{2}$. Roman Homosexuality, Oxford - New York: Oxford University Press.

Zeitlin, F. 1971. 'Petronius as Paradox: Anarchy and Artistic Integrity', TAPA 102, 631-684; reprinted in S.J. Harrison (ed.), Oxford Readings in the Roman Novel, Oxford: Oxford University Press, 1-49. 